\title{
HYGIENIC CHARACTERISTICS OF THE CHEMICAL COMPOSITION OF GROUNDWATER IN RYAZAN REGION
}

\author{
Solovyev DA ${ }^{1 \otimes}$, Dementiev $\mathrm{AA}^{1}$, Kluchnikova $\mathrm{NM}^{2}$, Prokhorov $\mathrm{NI}^{3}$ \\ 'Pavlov Ryazan State Medical University, Ryazan \\ ${ }^{2}$ Center for Hygiene and Epidemiology in Ryazan Region, Ryazan \\ ${ }^{3}$ Sechenov First Moscow State Medical University, Moscow
}

\begin{abstract}
Among the factors that have a strong impact on public health the environment, living conditions, food and water quality are just as important as socio-economic forces. Providing the population with access to safe potable water has become a socioeconomic priority in Russia. The aim of this work was to characterize the aquifers supplying the population of Ryazan region with water for personal and domestic needs and to compare their chemical composition. Sample collection was performed in cooperation with the Center for Hygiene and Epidemiology (Ryazan region). The obtained data were processed using ANOVA. The Kashirsky and Ozersko-Khovansky aquifers turn to be the most commonly used ones supplying water to $30.7 \%$ and $27.3 \%$ of the total artesian wells. The Oksko-Tarussky and Podolsko-Myachkovsky aquifers rank second, feeding $21 \%$ and $18.9 \%$ of the wells, respectively. The share of the Kasimovsky aquifer in the total water supply is only $2.1 \%$. Although the recommended lifespan of an artesian well is 25 years, two-thirds of the wells in Ryazan region have been in service for 26 to 50 years, and one in every 4 wells is over 50 years old. The chemical composition of the groundwater drawn from different aquifers is different. High concentrations $(0.7 \mathrm{mg} / \mathrm{l})$ of iron $\left(\mathrm{Fe}^{2+}\right)$ are present in the water from the Ozersko-Khovansky aquifer $(p \geq 0.05)$. Sulfates are found in abundance in the Podolsko-Myachkovsky and Ozersko-Khovansky aquifer. The water from the Oksko-Tarussky aquifer contains high concentrations of ionized ammonia.
\end{abstract}

Keywords: aquifers, interstitial waters, artesian waters, chemical composition of artesian waters, artesian wells

$\triangle$ Correspondence should be addressed: David A. Solovyev

Vysokovoltnaya 7, korp. 1, Ryazan, 390005; soldos1@yandex.ru

Received: 19.06.2018 Accepted: 26.10.2018

DOI: $10.24075 /$ brsmu.2018.055

\section{ГИГИЕНИЧЕСКАЯ ХАРАКТЕРИСТИКА ХИМИЧЕСКОГО СОСТАВА ВОДЫ ПОДЗЕМНЫХ ВОДОИСТОЧНИКОВ РЯЗАНСКОЙ ОБЛАСТИ}

Д. А. Соловьёв ${ }^{1 凶}$, А. А. Дементьев ${ }^{1}$, Н. М. Ключникова 2 Н. И. Прохоров ${ }^{3}$

${ }^{1}$ Рязанский государственный медицинский университет имени И. П. Павлова, Рязань

2 Центр гигиены и эпидемиологии в Рязанской области, Рязань

${ }^{3}$ Первый Московский государственный медицинский университет имени И. М. Сеченова (Сеченовский университет), Москва

Среди фракторов, влияющих на здоровье населения, кроме социально-экономических, большую роль играют состояние окружающей среды, условия быта, питание, водоснабжение. Обеспечение населения доброкачественной питьевой водой является важнейшим направлением социально-экономического развития России. Целью работы было охарактеризовать подземные водоносные горизонты, используемые для централизованного питьевого водоснабжения населения Рязанской области, и провести сравнительный анализ химического состава их артезианских вод. Материалом исследования служили данные о качестве воды водоносных горизонтов Рязанской области, полученные при совместной работе с ФБУЗ «Центр гигиены и эпидемиологии в Рязанской области». Использовали метод сравнительного анализа. Статистическую обработку проводили методом дисперсионного анализа. Чаще всего в районах Рязанской области для водоснабжения населения используются Каширский и Озерско-Хованский водоносные горизонты, на долю которых приходится соответственно 30,7 и 27,3\% скважин от их общего количества. Окско-Тарусский и Подольско-Мячковский водоносные горизонты используются реже (21 и 18,9\% скважин соответственно). Доля наиболее редко используемого Касимовского водоносного горизонта в целом по Рязанской области составляет 2,1\%. Хотя рекомендуемый срок использования артезианских скважин составляет 25 лет, две трети из них эксплуатируются от 26 до 50 лет, а каждая четвертая скважина - более 50 лет. Вода различных горизонтов области отличается по химическому составу. По сравнению с другими водоносными горизонтами, Озерско-Хованский характеризуется более высоким содержанием железа (Fe $\left.{ }^{2+}\right)$, концентрация которого составляет 0,7 мг/л ( $р \geq 0,05)$, Подольско-Мячковский и Озерско-Хованский - сульфатов, а Окско-Тарусский — ионов аммония.

Ключевые слова: водоносные горизонты, межпластовые воды, артезианские воды, химический состав, артезианские скважины

$\square$ Для корреспонденции: Давид Андреевич Соловьёв ул. Высоковольтная, 7, корп. 1, г. Рязань, 390005; soldos1@yandex.ru Статья получена: 19.06.2018 Статья принята к печати: 26.10.2018 DOI: $10.24075 /$ vrgmu.2018.055 
Among the factors that have a strong impact on public health the environment is just as important as socio-economic conditions; this is particularly true for drinking water [1, 2]. Providing the population with access to safe potable water has become a socio-economic priority in Russia [3, 4]. When it comes to public water supply, groundwater should be preferred over surface water [5-7]. This is because groundwater has a more stable chemical composition, is less likely to be contaminated with pathogenic bacteria and has better organoleptic properties [8, 9]. At the same time, groundwater sometimes contains high concentrations of chemical elements and compounds that exceed safety thresholds, depending on the sedimentary rocks that form an aquifer $[10,11]$. In Ryazan region, the majority of residential areas rely on groundwater sources [12-15]. Therefore, it is vital to monitor the quality of groundwater intended for public use. The aim of this study was to compare the chemical composition of groundwater drawn from different artesian wells across Ryazan region, the share of individual aquifers in the total water supply and the age and depth of the wells currently in service.

\section{METHODS}

Sample collection was done in cooperation with the Center for Hygiene and Epidemiology (Ryazan region). Groundwater samples were collected from every artesian well across Ryazan region once per season from 2010 through 2015 in strict compliance with the Sanitary rules and regulations (SanPIN 2.1.4.1074-01) [14]. The samples were tested for the presence of iron, sulfates and ionized ammonia. The depth and age of the wells were compared. The data were processed in Statistica 6 using ANOVA.

\section{RESULTS}

At present, there are 291 artesian wells in the region drawing water from different aquifers. The most commonly used aquifers are the Kashirsky and Ozersko-Khovansky supplying water to $30.7 \%$ and $27.3 \%$ of the wells, respectively. The Oksko-Tarussky and Podolsko-Myachkovsky aquifers have lower shares of $21 \%$ and $18.9 \%$, respectively. The Kasimovsky aquifer is the most rarely used one feeding $2.1 \%$ of the wells.

The quality of drinking water largely depends on the depth of the well. We compared the depth of the currently used artesian wells across Ryazan region and found out that almost two halves of them were more than $150 \mathrm{~m}$ deep, every fourth well reached 100 to $150 \mathrm{~m}$ in depth, and only $15 \%$ of wells drew water from shallower depths (Fig. 1).

The deepest wells (over $100 \mathrm{~m}$ ) are located on the territory of the Ozersko-Khovansky and Kasimovsky aquifers, making up $64 \%$ and $66 \%$ of the wells fed by each aquifer, respectively. Wells shallower than $50 \mathrm{~m}$ are typical for the Oksko-Tarussky aquifer (47.8\%).

Well age is an important factor in assessing the sanitary condition of the well and groundwater quality. The recommended lifespan of an artesian well is 25 years [13]. Our analysis reveals that the majority $(60 \%)$ of the wells for public water supply in Ryazan region have been in service for 26 to 50 years (Table 1). About one in every 4 wells is older than 50 years, while only $14.8 \%$ of the wells have been used for less than 25 years.

This trend is typical for the majority of aquifers except for Kasimovsky; two- thirds of the wells that draw water from this aquifer have been used for 25 years, while the rest are as old as 26 to 50 years.

The analysis of the chemical composition of the groundwater samples revealed that their salinity varied between 0.2 and $0.9 \mathrm{~g} / \mathrm{l}$. There were significant differences between the OzerskoKhovansky, Oksko-Tarussky and Podolsko-Myachkovsky aquifers in the concentrations of certain chemical compounds and elements. For example, the average iron concentrations in the Ozersko-Khovansy aquifer were $0.7 \mathrm{mg} / \mathrm{l}(p \geq 0.05)$, which exceeds the threshold of $0.3 \mathrm{mg} / \mathrm{l}$ established by the Russian hygiene standard 2.1.5.1315-03. Iron concentrations in the studied samples ranged from 0.035 to $8.22 \mathrm{mg} / \mathrm{l}$ and were above the established norm in $40 \%$ of cases [5]. The average concentrations of ionized ammonia in the Oksko-Tarussky aquifer differed significantly from those in the Kashirsky, Kasimovsky and Ozersko-Khovansy aquifers. Importantly, the average sulfate levels in the groundwater samples from the Oksko-Tarussky aquifer were 113.9 mg/l, differing significantly

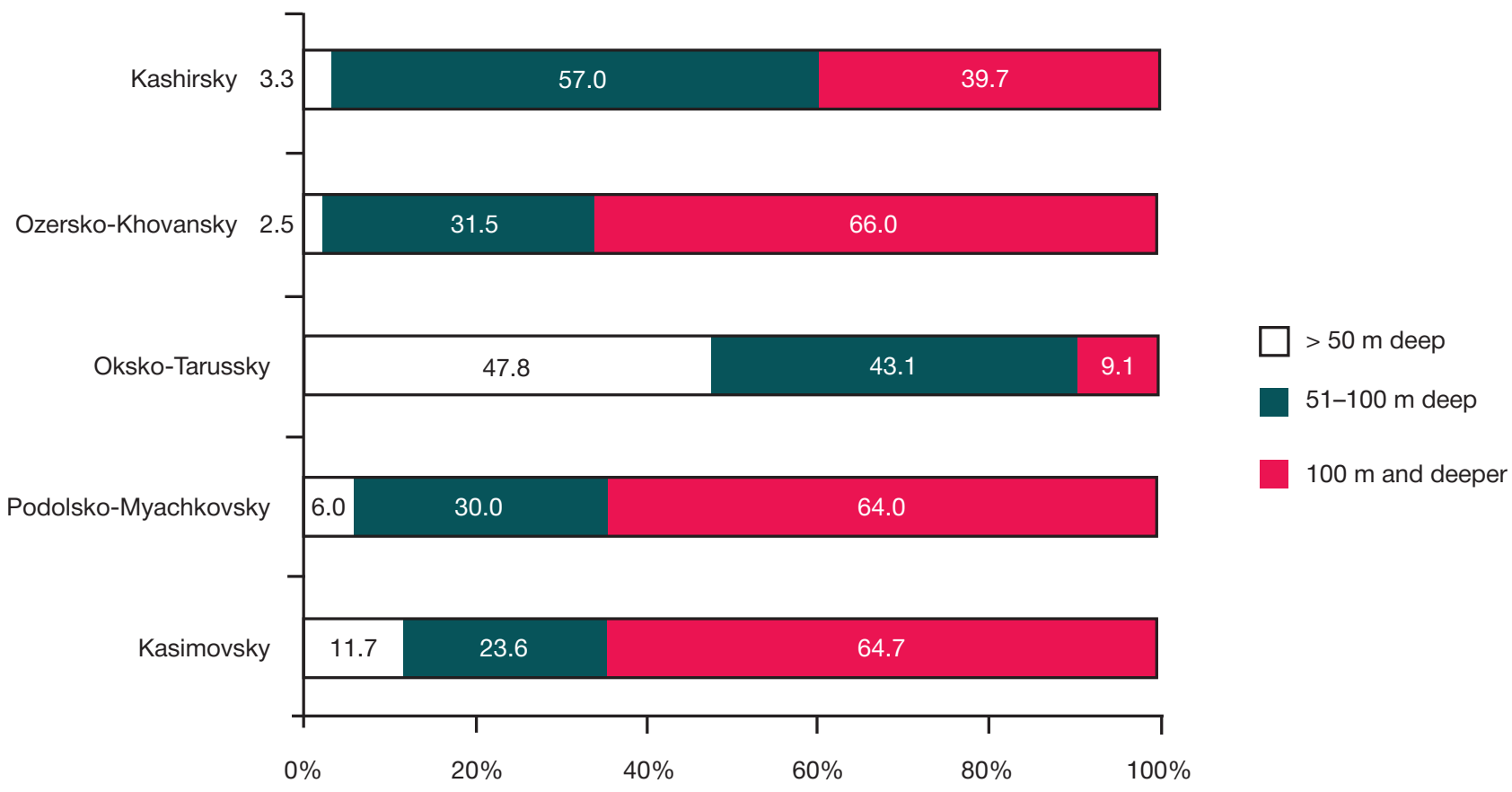

Fig. 1. The proportion of the artesian wells of various depth feeding from different aquifers 
ORIGINAL RESEARCH I HYGIENE AND EPIDEMIOLOGY

Table 1. The proportion of the artesian wells of various age feeding from different aquifers of Ryazan region

\begin{tabular}{|l|c|c|c|}
\hline \multirow{2}{*}{ Aquifer } & \multicolumn{2}{|c|}{ Proportion of artesian wells of various age, \% } \\
\cline { 2 - 4 } & $<25$ years & $26-50$ years & 50 years and above \\
\hline Kashirsky & 16.3 & 60.4 & 23.3 \\
\hline Ozersko-Khovansy & 16.9 & 60.0 & 23.1 \\
\hline Oksko-Tarussky & 13.6 & 65.5 & 20.9 \\
\hline Podolsko-Myachkovsky & 2.6 & 58.0 & 39.4 \\
\hline Kasimovsky & 64.7 & 35.3 & 0 \\
\hline
\end{tabular}

Table 2. The average concentrations of ionized ammonia, iron and sulfates in the studied groundwater sources

\begin{tabular}{|l|c|c|c|}
\hline \multirow{2}{*}{\multicolumn{1}{|c|}{ Aquifer }} & \multicolumn{2}{c|}{$\bar{x} \pm t m, \mathrm{mg} / \mathrm{ml}$} & Sulfates \\
\cline { 2 - 4 } & Ionized ammonia & Iron ions & $125.1 \pm 27.9$ \\
\hline Ozersko-Khovansy & $0.2 \pm 0.1$ & $0.7 \pm 0.2$ & $113.9 \pm 20.4$ \\
\hline Podolsko-Myachkovsky & $0.4 \pm 0.1$ & $0.3 \pm 0.1$ & $60.5 \pm 8.1$ \\
\hline Kashirsky & $0.2 \pm 0.1$ & $0.3 \pm 0.1$ & $43.4 \pm 22.4$ \\
\hline Kasimovsky & $0.2 \pm 0.1$ & $0.2 \pm 0.2$ & $54.5 \pm 6.1$ \\
\hline Oksko-Tarussky & $0.6 \pm 0.1$ & $0.4 \pm 0.1$ & \\
\hline
\end{tabular}

Note: $\bar{x}$ is the average concentration, $t m$ is confidence interval.

from the corresponding concentrations measured for other aquifers $(p \geq 0.05)$. Sulfate levels reached their minimum at $0.3 \mathrm{mg} / \mathrm{l}$ and maximum at $810 \mathrm{mg} / \mathrm{l}$. No significant differences between the aquifers were observed in the levels of fluorides, magnesium, manganese, bromine, beryllium, and chlorides.

To sum up, the concentrations of iron, sulfates and ionized ammonia differ significantly between the aquifers of Ryazan region (Table 2).

The levels of sulfates are higher in the PodolskoMyachkovsky and Ozersko-Khovansky aquifers than in their counterparts. The average concentration of ionized ammonia in the Oksko-Tarussky aquifer was higher than in other aquifers.

\section{DISCUSSION}

Ryazan region relies on the groundwater stored in the carboniferous and Upper Devonian water-bearing layers of the Moscow artesian basin. The majority of Ryazan aquifers are part of the carboniferous aquifer system. The aquifers studied in this article were formed by water percolating through gypsum deposits; therefore, the groundwater in them is rich in sulfates and calcium.

Our study demonstrates that groundwater samples collected across Ryazan region are different in their chemical composition, which can be explained by the history of the corresponding aquifers [1]. The Ozersko-Khovansky aquifer has increased concentrations of iron $(0.7 \mathrm{mg} / \mathrm{l}$ on average) exceeding those in other aquifers ( $p<0.05$ ); $40 \%$ of its groundwater samples do not meet the Russian hygiene standards of $0.3 \mathrm{mg} / \mathrm{l}$ (standard 2.1.5.1315-03). Such high figures mean that measures should be taken to deferrize the groundwater drawn from these artesian wells. The groundwater drawn from OzerskoKhovansky and Podolsko-Myachkovsky aquifers contains more sulfates (125.1 and $113.9 \mathrm{mg} / \mathrm{l}$, respectively) than other aquifers, which again can be explained by the specifics of their formation, such as gypsum dissolution [2]. Interestingly, the Oksko-Tarussky aquifer has the highest $(0.6 \mathrm{mg} / \mathrm{l})$ average concentrations of ionized ammonia $(p<0.05)$. However, the presence of ionized ammonia is not typical for this aquifer and can indirectly suggest organic contamination resulting from the misuse of the wells [2]. The supposition about the organic origin of ionized ammonia is underpinned by the fact that the wells drawing water from this aquifer are mostly shallow $(<50 \mathrm{~m}$ in depth) $(p<0,05)$ and the majority of them $(86.4 \%)$ have been in service longer than their recommended lifespan of 25 years. Obviously, shallower artesian wells are at a higher risk of surface water contamination. The large proportion of old (> 25 years) wells in Ryazan region prompts their renovation [16-18].

\section{CONCLUSIONS}

In Ryazan region, public water supply relies mainly on the groundwater of the Ozersko-Khovansky and Kashirsky aquifers. The deepest artesian wells $(\geq 100 \mathrm{~m})$ are located on the territory of the Kasimovsky and Podolsko-Myachkovsky aquifers where they also prevail. The Podolsko-Myachkovsky aquifer feeds the majority of the old wells ( $\geq 50$ years). The highest concentrations of sulfates are found in the PodolskoMyachkovsky and Ozersko-Khovansky aquifers, the highest levels of iron $\left(\mathrm{Fe}^{2+}\right)$ are observed for the Ozersko-Khovansky aquifer, and the highest concentrations of ionized ammonia are found in the Oksko-Tarussky aquifer. The groundwater drawn from the Ozersko-Khovansky aquifer does not meet the sanitary standards adopted in Russia (standard 2.1.5.1315-03) in terms of its iron levels, which are expected to be no higher than $0.3 \mathrm{mg} / \mathrm{l}$, and requires deferrization. Because we covered a very limited range of chemical elements and compounds in our study and the sampling schedule was arbitrary, there could be some uncertainties in the results of the analysis. Therefore, we believe it reasonable to conduct another study in order to compare the concentrations of fluorine and molybdenum in the groundwater of the same aquifers. On the whole, our study demonstrates that the quality of water drawn from the aquifers with different chemical composition should be monitored on a regular basis. Measures should be taken to deferrize the supplied groundwater and to renovate old artesian wells. 


\section{References}

1. Vinokurov Jul, Putilova AA. Analiz onkologicheskoj zabolevaemosti ee svjazej s faktorami okruzhajushhej sredy na territorii Altajskogo kraja. Geografija i prirodnye resursy. 2013; (4): 101-6.

2. Sjomka IM, Kazaeva OV. Analiz kachestva pit'evoj vody v Rjazanskoj oblasti. Nauka molodyh (Eruditio Juvenium). 2013; (3): $71-4$.

3. Zverev VP. Vlijanie antropogennoj dejatel'nosti na formirovanie himicheskogo sostava podzemnyh vod na osnovnyh urovnjah gidrosfery. SPb.: Nedra, 2002. 159-75.

4. Nedovesova SA, Trofimovich EM, Turbinskij W, Ajzman RI. Vlijanie dlitel'nogo potreblenija pit'evoj vody s povyshennym soderzhaniem magnija na funkcii pochek u zhivotnyh. Vestnik Novosibirskogo gosudarstvennogo pedagogicheskogo universiteta. 2016; (2): 45-7.

5. GOST 2761-84 Istochniki centralizovannogo hozjajstvennopit'evogo vodosnabzhenija. Gigienicheskie, tehnicheskie trebovanija i pravila vybora (s Izmeneniem № 1). Moskva: Standartinform, 2006; 142

6. GN 2.1.5.1315-03 Predel'no dopustimye koncentracii (PDK) himicheskih veshhestv $v$ vode vodnyh ob\#ektov hozjajstvennopit'evogo i kul'turno-bytovogo vodopol'zovanija. Moskva: Minzdrav Rossii, 2003; 47-105.

7. GOST 31861-2012. Mezhgosudarstvennyj standart. Voda. Obshhie trebovanija k otboru prob. Moskva: Standartinform, 2013; 14

8. Mihajlichenko KJu, Korshunova AJu, Kurbatova Al. Integral'naja ocenka kachestva pit'evoj vody centralizovannyh sistem vodosnabzhenija. Vestnik RUDN. Serija: Jekologija i bezopasnost' zhiznedejatel'nosti. 2014; (1): 76-9.

9. Kameneva MG, Korkina NA. Kachestvo vody i zdorov'e naselenija V sbornike: Itogi regional'noj konferencii, posvjashhjonnoj 95-letiju sanitarno-jepidemiologicheskoj sluzhby Rossii. 19 nojabrja 2014 g.; Kazan'. Vestnik Kazanskogo tehnologicheskogo universiteta, 2014; (4): 87.

\section{Литература}

1. Винокуров Ю. И., Путилова А. А. Анализ онкологической заболеваемости и ее связей с факторами окружающей средь на территории Алтайского края. География и природные ресурсы. 2013; (4): 101-6.

2. Сёмка И. М., Казаева О. В. Анализ качества питьевой воды в Рязанской области. Наука молодых (Eruditio Juvenium). 2013; (3): 71-4.

3. Зверев В. П. Влияние антропогенной деятельности на формирование химического состава подземных вод на основных уровнях гидросферы. СПб.: Недра, 2002. 159-75.

4. Недовесова С. А., Трофимович Е. М., Турбинский В. В., Айзман Р. И. Влияние длительного потребления питьевой воды с повышенным содержанием магния на функции почек у животных. Вестник Новосибирского государственного педагогического университета. 2016; (2): 45-7.

5. ГОСТ 2761-84 Источники централизованного хозяйственнопитьевого водоснабжения. Гигиенические, технические требования и правила выбора (с Изменением № 1) Москва: Стандартинформ, 2006; 142

6. ГН 2.1.5.1315-03 Предельно допустимые концентрации (ПДК химических веществ в воде водных объектов хозяйственнопитьевого и культурно-бытового водопользования. Москва: Минздрав России, 2003; 47-105.

7. ГОСТ 31861-2012. Межгосударственный стандарт. Вода. Общие требования к отбору проб. Москва: Стандартинформ 2013; 14.

8. Михайличенко К. Ю., Коршунова А. Ю., Курбатова А. И. Интегральная оценка качества питьевой водь централизованных систем водоснабжения. Вестник РУДН. Серия: Экология и безопасность жизнедеятельности. 2014; (1): 76-9.
10. Boronina LV, Sadchikov PN, Usynina AJe, Tazhieva SZ. Prognoz jekologicheskogo sostojanija poverhnostnyh vod Nizhnevolzhskogo bassejna. Jug Rossii: jekologija, razvitie. 2012; (3): 28-30.

11. Galimova AR, Tunakova JuA. Postuplenie, soderzhanie i vozdejstvie vysokih koncentracij metallov $v$ pit'evoj vode na organizm. Vestnik Kazanskogo tehnologicheskogo universiteta. 2013; (20): 165-9.

12. Srednie normativnye sroki sluzhby osnovnyh fondov uchrezhdenij i organizacij, sostojashhih na gosudarstvennom bjudzhete. M.: Statistika, 1972; 5

13. Pozdnjakova MA, Fedotova IV, Lipshic DA, Koroleva TA Statisticheskij podhod k gigienicheskoj ocenke kachestva pit'evogo vodosnabzhenija territorii v dinamike. Rossijskij medikobiologicheskij vestnik im. akad. IP. Pavlova. 2011; (2): 10.

14. SanPiN 2.1.4.1074-01 Pit'evaja voda. Gigienicheskie trebovanija k kachestvu vody centralizovannyh sistem pit'evogo vodosnabzhenija. Kontrol' kachestva. Gigienicheskie trebovanija k obespecheniju bezopasnosti sistem gorjachego vodosnabzhenija. Moskva, 2002; 19

15. Onishhenko GG. Jeffektivnoe obezzarazhivanie vody — osnova profilaktiki infekcionnyh zabolevanij. Vodosnabzhenie i sanitarnaja tehnika; 2005; 12 (1): 8-12.

16. Broholm MM, Aryin E. Biodegradation of phenols in a sandstone aquifer under aerobic conditions and nitrate and iron reducing conditions. J of Contaminant Hydrology. 2000; (3): 239-73.

17. Fryar AE, Macko SA, Mullican WF, Romanak KD, Bennet PC. Nitrat reduction during ground-water recharge, Southern High Plains, Texas. J of Contaminant Hydrology. 2000; (2): 335-63.

18. Kaluarachchi JJ, Cvetkovic V, Berglund S. Stochastic analysis of oxygen- and nitrate-based biodegradation of hydrocarbons in aquifer. J of Contaminant Hydrology. 2000; (3): 335-65.
9. Каменева М. Г., Коркина Н. А. Качество воды и здоровье населения. В сборнике: Итоги региональной конференции, посвященной 95-летию санитарно-эпидемиологической службы России. 19 ноября 2014 г.; Казань. Вестник Казанского технологического университета, 2014; (4): 87.

10. Боронина Л. В., Садчиков П. Н., Усынина А. Э., Тажиева С. 3. Прогноз экологического состояния поверхностных вод Нижневолжского бассейна. Юг России: экология, развитие. 2012; (3): 28-30.

11. Галимова А. Р., Тунакова Ю. А. Поступление, содержание и воздействие высоких концентраций металлов в питьевой воде на организм. Вестник Казанского технологического университета. 2013; (20): 165-9.

12. Средние нормативные сроки службы основных фондов учреждений и организаций, состоящих на государственном бюджете. М.: Статистика, 1972: 5.

13. Позднякова М. А., Федотова И. В., Липшиц Д. А., Королева Т. А Статистический подход к гигиенической оценке качества питьевого водоснабжения территории в динамике. Российский медико-биологический вестник им. акад. И. П. Павлова. 2011; 19 (2): 10

14. СанПиН 2.1.4.1074-01 Питьевая вода. Гигиенические требования к качеству воды централизованных систем питьевого водоснабжения. Контроль качества. Гигиенические требования к обеспечению безопасности систем горячего водоснабжения. Москва, 2002; 19.

15. Онищенко Г. Г. Эфффективное обеззараживание воды основа профилактики инфекционных заболеваний. Водоснабжение и санитарная техника. 2005; 12 (1): 8-12.

16. Broholm MM, Aryin E. Biodegradation of phenols in a sandstone aquifer under aerobic conditions and nitrate and iron reducing 


\section{ORIGINAL RESEARCH I HYGIENE AND EPIDEMIOLOGY}

conditions. J of Contaminant Hydrology. 2000; (3): 239-73.

17. Fryar AE, Macko SA, Mullican WF, Romanak KD, Bennet PC. Nitrat reduction during ground-water recharge, Southern High Plains, Texas. J of Contaminant Hydrology. 2000; (2): 335-63.
18. Kaluarachchi JJ, Cvetkovic V, Berglund S. Stochastic analysis of oxygen- and nitrate-based biodegradation of hydrocarbons in aquifer. J of Contaminant Hydrology. 2000; (3): 335-65. 